\title{
Utilization of steel melting electric arc furnace slag for development of vitreous ceramic tiles
}

\author{
RITWIK SARKAR*, NAR SINGH ${ }^{\dagger}$ and SWAPAN KUMAR DAS ${ }^{\dagger}$ \\ Department of Ceramic Engineering, National Institute of Technology, Rourkela 769 008, India \\ ${ }^{\dagger}$ Refractories Division, Central Glass \& Ceramic Research Institute, Kolkata 700 032, India
}

MS received 20 March 2008

\begin{abstract}
Steel melting through electric arc furnace route is gaining popularity due to its many advantages, but generates a new waste, electric arc furnace slag, which is getting accumulated and land/mine filling and road construction are the only utilization. This slag has been tried to be value added and utilized to develop vitreous ceramic tiles. Slag, to the extent of 30-40 $\mathrm{w}$ \% with other conventional raw materials, were used for the development in the temperature range $1100-1150^{\circ} \mathrm{C}$. The fired products showed relatively higher density with shorter firing range and good strength properties. Microstructural and EDAX studies were also done to evaluate the developed products.
\end{abstract}

Keywords. EAF slag; composition; vitrification; ceramic tiles.

\section{Introduction}

Demand and production of steel is increasing day by day and all the developing countries like China, India are increasing their production capacity significantly. Total world steel production has crossed 1200 million metric tons and the leader China is producing more than one third of it. Steel production by electric arc furnace route has gained momentum after eighties and consists of around $50 \%$ of the total steel production by advanced countries. This route of steel production has several advantages over the conventional blast furnace and converter route. These are mainly: Low capital cost and lower energy requirement per ton of steel, allows the utilization of waste steel scraps, precise control on chemistry and temperature of steel, flexibility in the size of the furnace (can be very small for special alloys) and very high temperature may be achieved by arcing.

But due to this change in the steel making technology, there appears a new by-product: electric arc furnace (EAF) slag (also commonly called as black slag). The conventional blast furnace slag is widely being consumed by the cement and concrete manufacturing units due to the presence of the pozzolonic activity of the same (Hogan and Muesel 1981; Fultron 1984; Hwang and Lin 1986; Sakai et al 1993; Nkinamubanzi et al 1998; Regourd 1998). But this EAF slag has no such characteristics and on contrary has very high iron content (in metallic or oxide form).

According to a published data (Malcolm et al 1993), $72 \%$ of total EAF waste has been disposed of for landfills

*Author for correspondence (ritwiksarkar@rediffmail.com) and to a lesser extent, is used for zinc recovery and for fertilizer manufacture. However, the landfills are not the sole solution in the medium and long term due to different technical, social and environmental aspects (Reinhart 1993). For this reason, one of the greatest reoccupations of the researchers of the present time is to establish a correct management of this kind of slags. In order to reduce or minimize the great volume of slags produced, different alternatives are studied, the main alternative being recycled aggregate in road constructions (Fallman and Kartlen 1997; Lind et al 2000; Nagataki et al 2000). This alternative can be an effective idea (Sakata and Ayano 2000) to solve serious problems because of the requirement to protect the natural environment is increasing and the supply capacity of good quality sand or gravel is decreasing.

Several studies have been made on the characteristics of EAF oxidizing slag with respect to its application in the construction industry, in particular of its attributes as a material (Luxan et al 2000; Rojas and Sanchez de Rojas 2004; Manso et al 2006; Bernardo et al 2007), its potential expansivity (Rojas et al 2002) and its chemical reactivity (Vázquez and Barra 2001). The possibility of EAF slag being used satisfactorily in concrete has been demonstrated (Young et al 2002; Beshr et al 2003; Maslehuddin et al 2003). The principal problems that remain is the durability of this type of concrete (Morino and Iwatsuki 1999; Geyer et al 2001) and its environmental tolerance (Hino and Miki 2001). Correctly manufactured EAF slag concrete has good mechanical properties, and its high density is an advantageous property where weight is a key factor, in such constructions as breakwater blocks, foundations, shoring walls, noise barriers, and radiation insulators, among others. 
Table 1. Physico-chemical characteristics of the starting materials.

\begin{tabular}{|c|c|c|c|c|c|}
\hline \multirow[b]{2}{*}{ Oxides } & \multicolumn{5}{|c|}{ Chemical analysis (wt\%) } \\
\hline & EAF slag & $B$-clay & $T$-clay & Quartz & Feldspar \\
\hline $\mathrm{SiO}_{2}$ & $20 \cdot 3$ & 57.78 & 63.45 & $99 \cdot 55$ & 66.48 \\
\hline $\mathrm{Al}_{2} \mathrm{O}_{3}$ & $7 \cdot 3$ & 24.73 & $15 \cdot 98$ & 0.03 & $17 \cdot 29$ \\
\hline $\mathrm{Fe}_{2} \mathrm{O}_{3}$ & $42 \cdot 4$ & $5 \cdot 01$ & 0.57 & 0.03 & $0 \cdot 14$ \\
\hline $\mathrm{TiO}_{2}$ & $0 \cdot 32$ & $0 \cdot 46$ & $1 \cdot 01$ & $0 \cdot 01$ & $0 \cdot 02$ \\
\hline $\mathrm{CaO}$ & $22 \cdot 8$ & $0 \cdot 59$ & $0 \cdot 80$ & $0 \cdot 03$ & $0 \cdot 31$ \\
\hline $\mathrm{MgO}$ & $8 \cdot 0$ & 1.91 & $0 \cdot 34$ & 0.01 & 0.03 \\
\hline $\mathrm{Na}_{2} \mathrm{O}$ & $0 \cdot 63$ & $1 \cdot 04$ & $0 \cdot 22$ & $0 \cdot 03$ & $2 \cdot 94$ \\
\hline $\mathrm{K}_{2} \mathrm{O}$ & $0 \cdot 82$ & 1.46 & $0 \cdot 39$ & 0.02 & 11.95 \\
\hline LOI & & $6 \cdot 71$ & $16 \cdot 79$ & $0 \cdot 21$ & 0.71 \\
\hline \multirow[t]{2}{*}{ Phase analysis, major } & wustite and & kaolinite & kaolinite & quartz & orthoclase \\
\hline & bredigite & quartz & quartz & & microcline \\
\hline
\end{tabular}

There is no information available in the literature about the value addition to this waste and to make it as a commonly useful conventional product. In the present study, an attempt has been made to develop vitreous ceramic tiles utilizing $30-40 \mathrm{wt} \%$ of EAF slag. EAF slag was first crushed and then mixed with conventional ingredients of vitreous tile making components, milled, pressed and fired. Fired products were characterized for various conventional tiles properties as well as microstructure and EDAX study.

\section{Experimental}

The raw materials used in the study are electric arc furnace slag (Essar Steel Ltd, India), quartz powder (Tamil $\mathrm{Nadu}$, India), T-clay (Thangarh, India), B-clay (Baruipur, India) and feldspar (Ranchi, India). First the raw materials were chemically analysed and tested for the phases present by X-ray diffraction method. Details of the raw materials characteristics are provided in table 1 . The raw materials were then mixed according to the compositions, given in table 2. EAF slag was first crushed to below $1 \mathrm{~mm}$ size and then used for batch making. One kilogram batch of each composition was prepared by wet milling in a pot mill for $6 \mathrm{~h}$ at a speed of $35 \mathrm{rpm}$. The slurries were dried and disintegrated. Dry powders were thoroughly mixed with 5-6 wt.\% water and rectangular bars $(100 \times$ $15 \times 6 \mathrm{~mm})$ and tiles $(100 \times 100 \times 6 \mathrm{~mm})$ were prepared using uniaxial compaction at a specific pressure of $25 \mathrm{MPa}$. The compacted bars were dried at $110^{\circ} \mathrm{C}$ till the moisture content was reduced to $<0.5 \mathrm{wt} \%$ and then fired in the temperature range of $1100-1150^{\circ} \mathrm{C}$ for a soaking period of $1 \mathrm{~h}$ in an electric furnace. The fired samples were then subjected to various tests including linear shrinkage, bulk density, water absorption, flexural strength and acid and alkali resistance. Polished and etched (using 10\% HF solution) samples were used for the microstructural analysis by secondary electron image and energy dispersive X-ray analysis (EDAX) study using back scattered electron image.
Table 2. Composition of the batches.

\begin{tabular}{lccccc}
\hline Contents & Batch $P$ & Batch $Q$ & Batch $R$ & Batch $S$ & Batch $T$ \\
\hline EAF slag & 40 & 40 & 30 & 40 & 40 \\
B-clay & 50 & 40 & 40 & 20 & - \\
$T$-clay & - & - & - & 20 & 40 \\
Quartz & 10 & 10 & 10 & 10 & 10 \\
Feldspar & - & 10 & 20 & 10 & 10 \\
\hline
\end{tabular}

For chemical analysis, gravimetric method was utilized to determine $\mathrm{SiO}_{2}$ and $\mathrm{Al}_{2} \mathrm{O}_{3}$ contents, whereas $\mathrm{Fe}_{2} \mathrm{O}_{3}$, $\mathrm{CaO}$ and $\mathrm{MgO}$ were determined volumetrically (Hillebrand and Lundell 1953). Alkalis were determined by flame photometry and loss on ignition test was carried out on ignition at $1000^{\circ} \mathrm{C}$ for $1 \mathrm{~h}$. The crystalline phases present in the raw materials were identified by XRD (Philips 'X-Pert Pro' diffraction unit attached with secondary monochromator, automatic divergence slit and nickel filter to get monochromatic $\mathrm{Cu}-\mathrm{K} \alpha$ radiation). Bulk density, apparent porosity and water absorption were determined by conventional liquid displacement method using Archimedes's principle by boiling water method. An Instron $5500 \mathrm{R}$ machine was utilized to determine flexural strength. Acid and alkali resistance of the samples were tested as per Indian Standard IS 13630 part 7 [IS 13630-2003]. Microstructural analysis was done in a scanning electron microscope (Leica make model S-430i) attached with electron diffraction X-ray analysis (EDXA) facility for quantitative elemental analysis.

\section{Results and discussion}

Characteristics of the raw materials indicate that EAF slag contains very high amount of iron oxide, lime, silica and magnesia. Presence of very high amount of iron oxide may restrict the use of this material in a ceramic composition, as it may reduce the firing temperature and vitrification range. Silica, lime and magnesia may be accommodated in the ceramic compositions. Phase analysis 
shows wustite $(\mathrm{FeO})$ and gehlenite $\left(2 \mathrm{CaO}, \mathrm{Al}_{2} \mathrm{O}_{3}, \mathrm{SiO}_{2}\right)$ as the major phase and bredigite $\left(14 \mathrm{CaO} 2 \mathrm{MgO} 8 \mathrm{SiO}_{2}\right)$ as the minor one. B-clay has iron oxide as the major impurity and has higher silica content and less LOI. Phase analysis indicates the presence of free quartz. T-clay has high amount of loss on ignition and indicates the presence of biomass in the same. T-clay has also much low alumina content and may reduce the firing temperature and firing range of the ceramic composition. Phase analysis indicates the presence of free quartz in T-clay. Quartz and feldspar are relatively pure as per composition and phase analysis.

\subsection{Densification study}

Densification study of the samples is provided in figures 1-4 as linear shrinkage, bulk density, apparent porosity

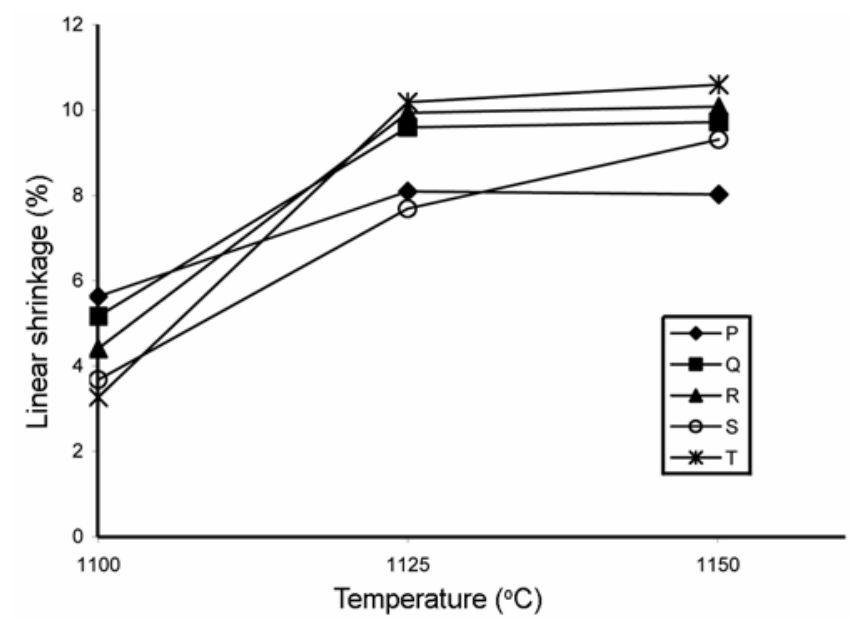

Figure 1. Variation of percent linear shrinkage against firing temperature.

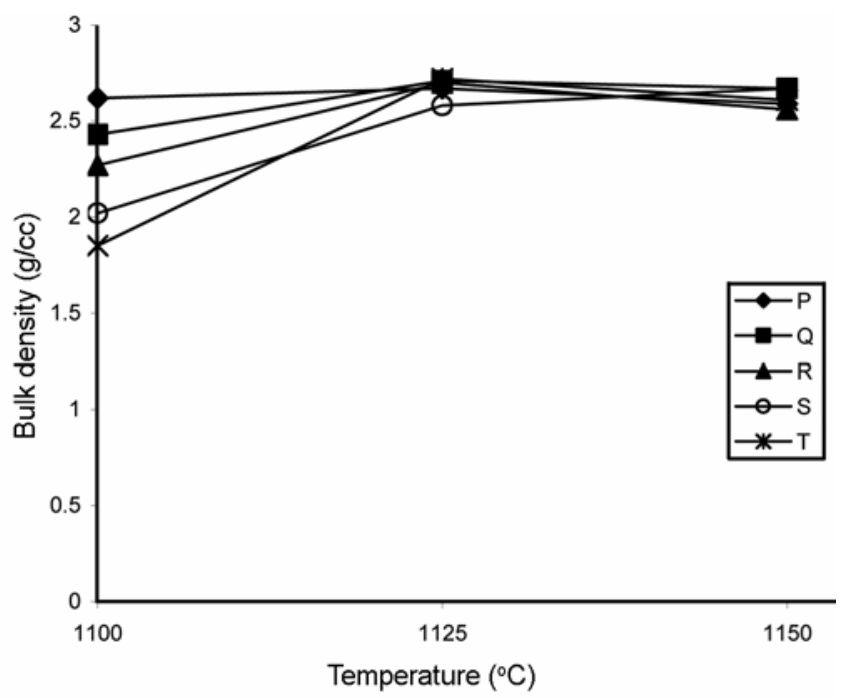

Figure 2. Variation of bulk density against firing temperature. and water absorption against the firing temperature. From all the plots it is evident that the samples are poorly densified at $1100^{\circ} \mathrm{C}$. Increase in firing temperature increases the shrinkage and density and reduces the apparent porosity and water absorption values for all the compositions. This change is very sharp for the batches $R$ and $T$. Near zero percent water absorption (vitrification) was achieved for these compositions even at $1125^{\circ} \mathrm{C}$ and for other three batches the vitrification was achieved at $1150^{\circ} \mathrm{C}$. This indicates that batches $R$ and $T$ have a very short vitrification range; this may be due to the presence of higher amount of feldspar (flux) in the $R$ batch and presence of higher amount of $T$-clay (very low alumina content) and no $B$-clay in the $T$ batch. In general, all the batches follow the general trend of sintering and densification, but at $1150^{\circ} \mathrm{C}$ there is a slight decrease in the shrinkage and density values, particularly for the $R$ and $T$ batches. This

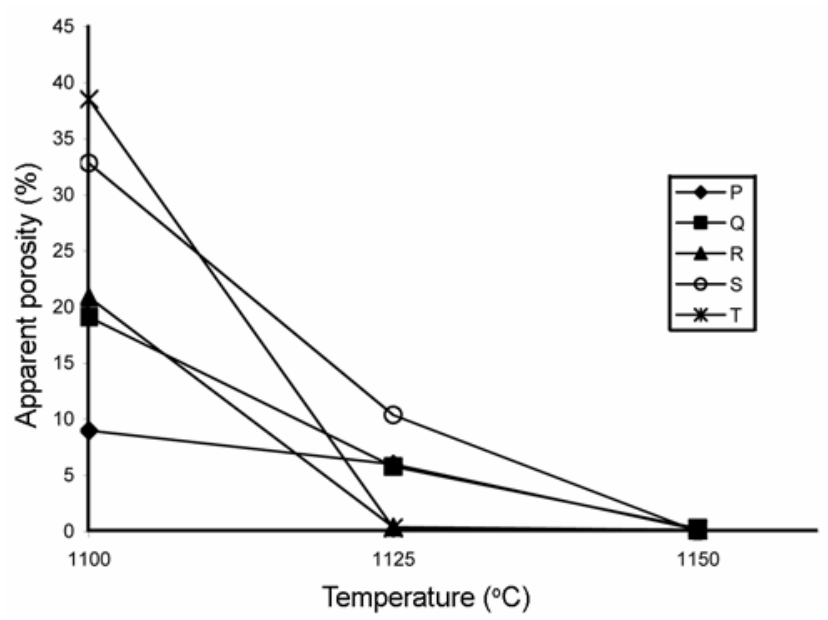

Figure 3. Variation of apparent porosity against firing temperature.

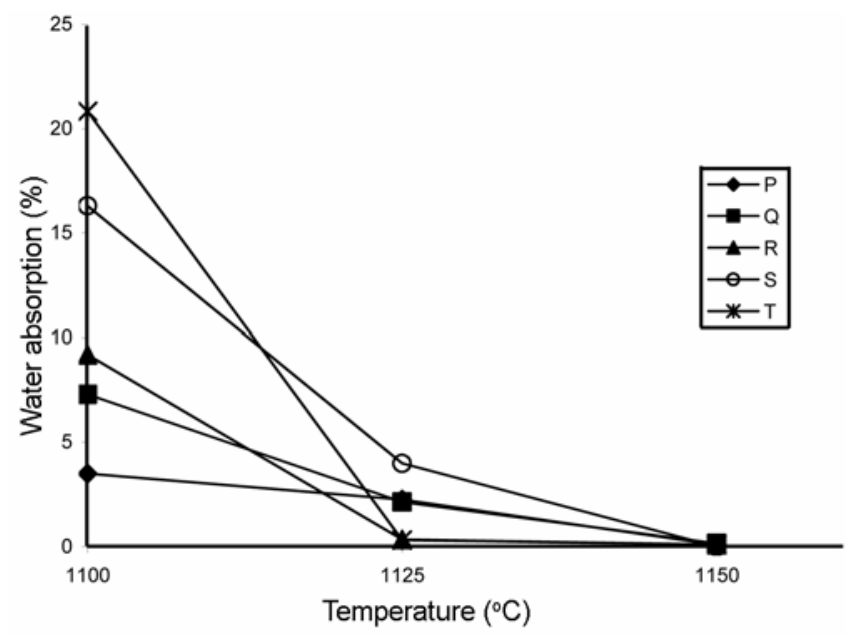

Figure 4. Variation of water absorption against firing temperature. 
may be due to the early vitrification of the compositions, resulting over firing, grain growth and re-crystallization. In general, the density values are relatively higher than the conventional vitreous ceramic tiles due to the presence of high amount of iron oxide.

\subsection{Strength study}

Cold strength (three point bending strength) of the batches showed poor value at $1100^{\circ} \mathrm{C}$ firing but increases sharply with increasing temperature (figure 5). The increase is sharp for the $R$ and $T$ batches due to the achievement of the vitrification at $1125^{\circ} \mathrm{C}$ but strength again falls at further high temperature for these two batches, which may be associated with over firing, grain growth and re-crystallization. For other three batches, strength increases with increase in the firing temperature but the increase is much significant above $1125^{\circ} \mathrm{C}$ firing.

\subsection{Microstructure and EDAX study}

The secondary electron image and back scattered electron image (for EDAX study) using scanning electron microscope of the polished and etched specimens fired at $1125^{\circ} \mathrm{C}$ are shown in figures 6 and 7 . Batches $P, S$ and $T$ are shown as representative ones. The microstructure of all the batches are in general highly compacted with nearly no inter-granular or intra-granular porosity. But the grains are nonuniform in size with roundish shape. This indicates liquid phase sintering or vitrification in the compositions resulting in the rounding of the edges of the grains. EDAX study reveals that in general all the batches consist of silica grains with some high iron oxide containing grains and some grains consist of mainly alumina and lime and also silica, iron oxide, alkali and magnesia to a

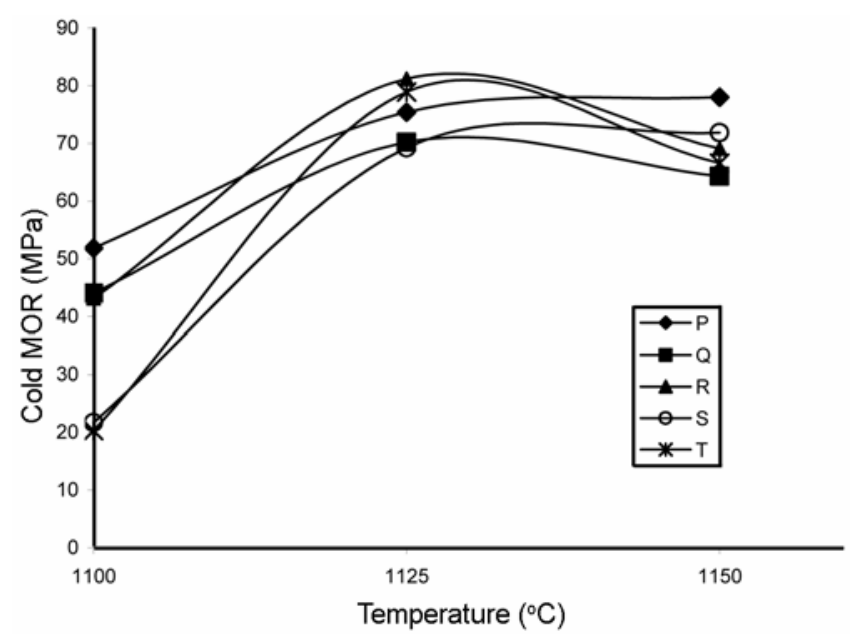

Figure 5. Variation of cold strength (MOR) against firing temperature. lesser extent. Presence of un-reacted silica grains in the microstructure in all the batches indicates that quartz has not reacted with the other ingredients at this temperature level. High iron oxide containing grains (found as white portions in the back scattered image) in the batches are
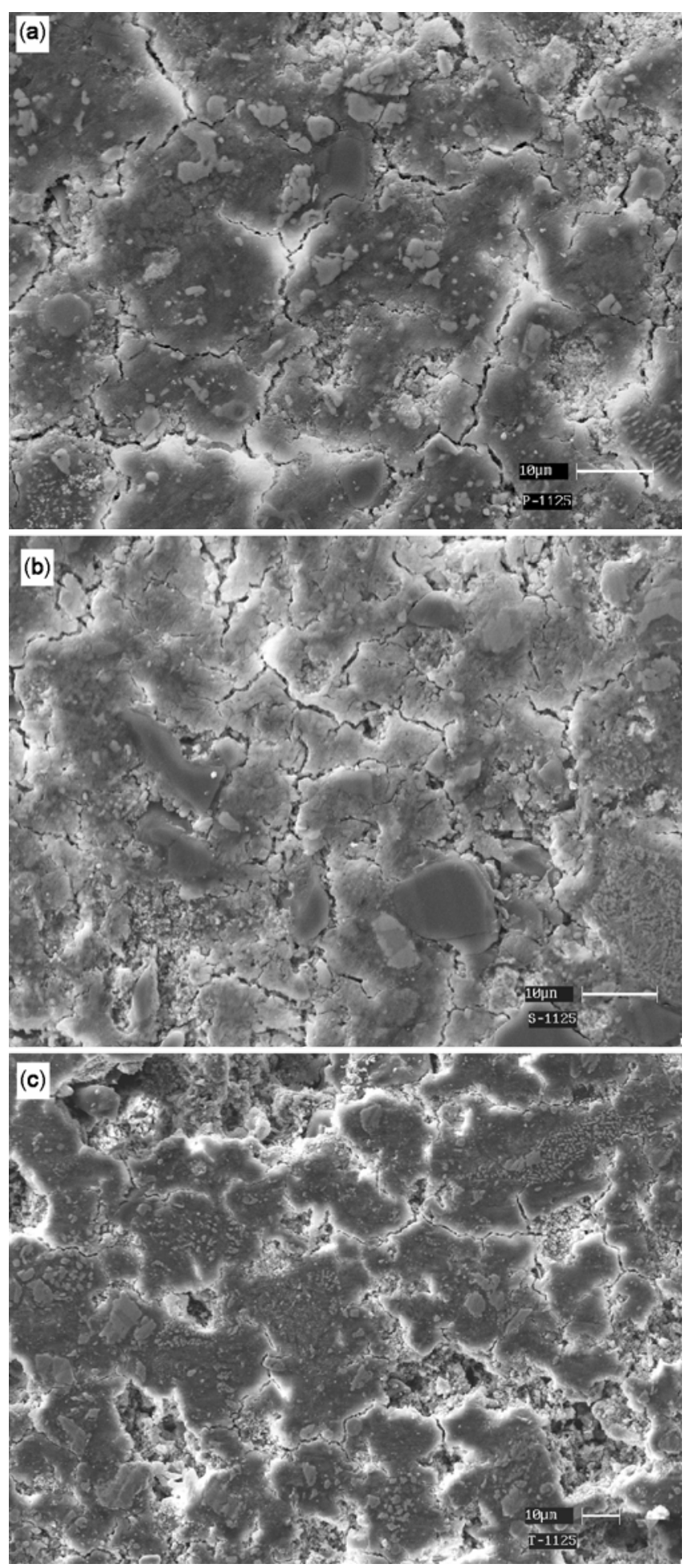

Figure 6. Scanning electron micrographs of the (a) batch $\mathrm{P}$, (b) batch $\mathrm{A}$ and (c) batch $\mathrm{T}$ fired at $1125^{\circ} \mathrm{C}$. 

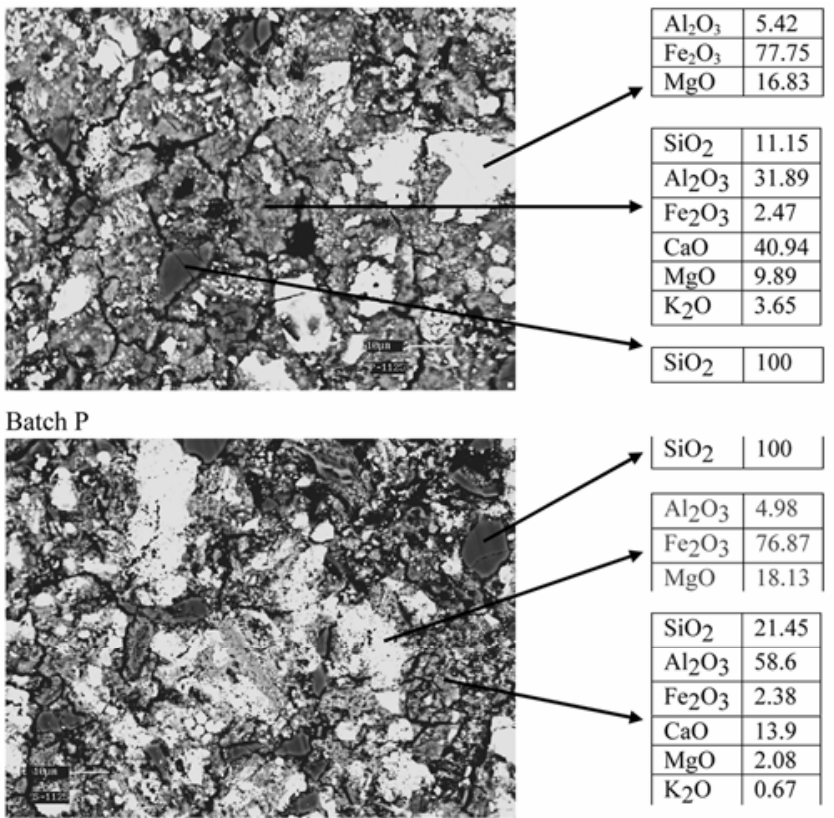

Batch S

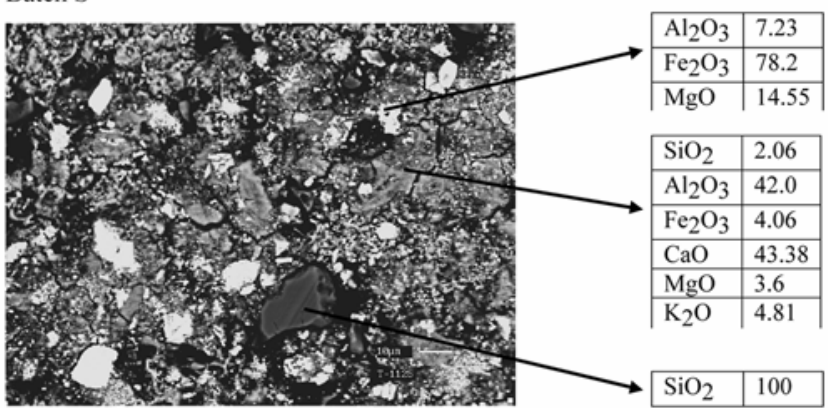

Batch T

Figure 7. Energy dispersive X-ray analysis of the batches fired at $1125^{\circ} \mathrm{C}$, represented as the oxide content of the analysed portions.

the reacted portion of the slag particles which reacted with the clays and feldspars and resulted in other grains which were found to be grayish in colour in figure 7. EAF slag, containing considerable amount of $\mathrm{CaO}, \mathrm{SiO}_{2}$, $\mathrm{Al}_{2} \mathrm{O}_{3}$ and $\mathrm{MgO}$ reacts with feldspar and clay and forms the glassy phase. Un-reacted quartz grains are distributed throughout. Cracks are observed in the quartz grains, probably due to difference in thermal expansion coefficient with other microstructural constituents during cooling process. Stronger pre-stress thus developed may be responsible for the higher flexural strength in the batches. Similar observation was also found (Zsolnay 1957) for conventional triaxial porcelain.

\section{Conclusions}

Steel melting electric arc furnace (EAF) slag can be utilized as a component in the development of vitreous ceramic tiles. But the developed tiles are having relatively higher density value due to presence of heavier iron oxide. Again use of EAF slag showed relatively short vitrification range for all the compositions, even on the use to the extent of $30-40 \mathrm{wt} \%$ in the composition. Presence of higher amount of feldspar and also higher amount of low alumina containing clay showed further reduced vitrification range for the compositions. A little reduced flexural strength was obtained when complete vitrification was obtained, which may be associated with grain growth and re-crystallization. In the microstructural study quartz was found to be un-reacted at $1125^{\circ} \mathrm{C}$ for all the compositions and iron oxide rich portion (remnant of slag) and alumina, lime, silica containing compound was found as the other microstructural constituents.

\section{Acknowledgements}

The authors would like to thankfully acknowledge the financial support of M/s Essar Steel Ltd, Hazira, India, for financial support and also acknowledge the contribution of the XRD and SEM sections of the Institute for help in the experiments.

\section{References}

Bernardo G, Marroccoli M, Nobili M, Telesca A and Valenti G L 2007 Resour. Conserv. Recy. 5295

Beshr H, Almusallam A A and Maslehuddin M 2003 Constr. Build. Mater. 1797

Fallman A M and Kartlen J 1997 Utilization of electric arc furnace steel slag in road construction, in Characterization of residues release of contaminants from slag ash ashes (ed.) A M Fallman, Diss. Department of Physics and Measurement Technology, Linkoping University, Sweden

Fultron F S 1988 The properties of Portland cement containing milled granulated blast-furnace slag, Portland Cem. Inst. Memogr. pp 4-66

Geyer R T, Dal Molin D and Vilella A 2001 Availaçao da durabilidade do concreto armado com adicao de escoria d'aciaria eletrica $56^{\circ}$ Congreso ABM, Belo Horizonte pp 127-136 (Spanish)

Hillebrand W F and Lundell G E F 1953 Applied inorganic analysis (New York: John Wiley and Sons) 2nd edn

Hino M and Miki T 2001 New role of steelmaking slags for the environmental protection of ocean, Shiraishi Memorial Lecture of the Iron Institute of Japan, Tokyo (Japan: ISIJ Publications) $99 \mathrm{pp} 44-45$

Hogan F J and Muesel J W 1981 Cem. Concr. Aggreg. 340

Hwang C L and Lin C Y 1986 Strength development of blended blast furnace slag cement mortars, SP 91-65 Proceedings of the 2nd International conference on fly ash, silica fume, slag and natural pozzolans in concrete, Madrid, Spain (ed.) V M Malhotra (Detroit, MI, USA: American Concrete Institute) Vol. 2 pp 1323-1340

Indian standard specification IS 13630-2003, Ceramic tiles methods of test, Part 7 - determination of chemical resistance for unglazed tiles 
Lind B B, Fallman A M and Larsson L B 2000 Environmental impact of ferrochrome slag in road construction, in Int. conf. on the science and engineering of recycling for environmental protection, WASCON 2000 Harrogate, UK (eds) G R Woolley et al (Amsterdam: Elsevier) Vol. I pp. 247-249

Luxán M P, Sotolongo R and Herrero E 2000 Cem. Concr. Res. 30517

Malcolm T, Tylko J K and Han H 1993 Waste Manag. Res. 11 415

Manso J M, Polanco J A, Losañez M and González J J 2006 Cem. Concr. Compos. 28528

Maslehuddin M, Sharif A M, Shameem M, Ibrahim M and Barry M S 2003 Constr. Build. Mater. 7105

Morino K and Iwatsuki E 1999 Durability of concrete using electric arc furnace oxidizing slag aggregates, in Proceedings of international conference (ed.) N Swamy (Sheffield) pp 213-222

Nagataki S, Gotice A and Saeki T 2000 Effect of recycled aggregate characteristics on performance parameters of recycled aggregate concrete, in 5th Int. conf. on durability of concrete, CANMET/ACI Barcelona, Spain (ed.) V M Malhotra (Detroit, USA: Am. Concrete Inst.) Vol. I, pp. 51-71
Nkinamubanzi P C, Baalbaki M, Bickley J and Aitcin P C 1998 The use of slag for making high performance concrete, Sixth $N C B$ international seminar on cement and building materials (New Delhi: NCB) XIII pp. 13-39

Regourd M M 1998 Cements made from blast-furnace slag, Lea's chemistry of cement and concrete (Amsterdam: E1sevier) pp 633-674

Reinhart D R 1993 Waste Manag. Res. 11257

Rojas M F and Sánchez de Rojas M I 2004 Cem. Concr. Res. 34 1881

Rojas M F, Sánchez de Rojas M I and Uria A 2002 Mater. Construct. $\mathbf{5 2} 79$

Sakai K, Watanabe H, Suzuki M and Hamazaki K 1993 Properties of granulated blast-furnace slag cement concrete (Detroit, USA: ACI Spec. Publ.) SP-132 pp 1367-1383

Sakata K and Ayano T 2000 Improvement of concrete with recycled aggregate, in 5th Int. conf. on durability of concrete (ed.) V M Malhotra (Barcelona, Spain: CANMET/ACI) Vol. II, pp. 1089-1108

Vázquez R E and Barra M 2001 Mater. Construct. 51137 Young H M, Hoon Y J and Soo K S 2002 Geosyst. Eng. 538

Zsolnay L M 1957 J. Am. Ceram. Soc. 40299 